\title{
ОЦЕНКА ЭФФЕКТИВНОСТИ ПРОИЗВОДСТВЕННО-ТЕХНОЛОГИЧЕСКОЙ ИНФРАСТРУКТУРЫ ИННОВАЦИОННОЙ ДЕЯТЕЛЬНОСТИ НА ПРИМЕРЕ ТЕХНОПАРКОВ РОССИИ
}

\author{
(C) 2021 Кох Ю.П. \\ Санкт-Петербургский политехнический университет Петра Великого, Россия, Санкт-Петербург \\ E-mail: sidorova.iulia2010@yandex.ru \\ (C) 2021 Дегтерева В.А. \\ Санкт-Петербургский политехнический университет Петра Великого, Россия, Санкт-Петербург \\ E-mail: degtereva_va@spbstu.ru
}

Представленная статья посвящена анализу эффективности функционирования технологических парков России. Авторами статьи проанализированы показатели развития технопарков России в динамике, определены существующие методики оценки эффективности технопарков России, выделены их особенности, положительные стороны и недостатки, предложен механизм оценки эффективности деятельности технопарков России посредством оболоченного анализа данных (Data Envelopment Analysis, DEA), определяющего техническую эффективность технопарков (максимизация результатов деятельности), произведен расчет технической эффективности 40 технопарков России, полученные результаты эффективности сравнены с результатами национального рейтинга технопарков России 2019 года, формируемого Ассоциацией кластеров и технопарков России. Сделаны соответствующие выводы.

Ключевые слова: техническая эффективность, технологический парк, технопарк, инфраструктура инновационной деятельности, метод оболоченного анализа данных, Data Envelopment Analysis.

\section{Введение}

Согласно ст. 2 Федерального закона от 23.08.1996 № 127-ФЗ (ред. от 25.05.2020) «О науке и государственной научно-технической политике» инновационная инфраструктура - это совокупность организаций, способствующих реализации инновационных проектов, включая предоставление управленческих, материальнотехнических, финансовых, информационных, кадровых, консультационных и организационных услуг.

Производственно-технологическая инфраструктура обеспечивает доступ инновационных производств к производственной среде и является одним из видов инфраструктуры инновационной деятельности $[1,2]$.

$\mathrm{K}$ производственно-технологической инфраструктуре инновационной деятельности относят инновационно-технологические центры, технопарки, инновационно-промышленные парки, технологические кластеры, техниковнедренческие зоны, центры коллективного использования технологий, бизнес-инкубаторы, инжиниринговые центры, центры кластерного развития, особые экономические зоны, наукограды, территории опережающего развития, спинауты, внутренние венчуры, территори инновационного развития [3, 4].

Целью исследования является оценка эффективности производственно-технологической инфраструктуры инновационной деятельности на примере технологических парков России.

Задачи исследования: проанализировать показатели развития технопарков России в динамике, определить существующие методы и механизмы оценки эффективности технопарков России, выделить их особенности, положительные стороны и недостатки; предложить механизм оценки эффективности деятельности технопарков России посредством оболоченного анализа данных, провести оценку технопарков России посредством оболоченного анализа данных, сравнить результаты оценки эффективности посредством метода оболоченного анализа данных и результаты оценки, полученные Ассоциацией кластеров и технопарков России.

Материалы и методы исследования: обзор литературы, анализ, обобщение, систематизация, сравнение, интерпретация, сопоставление, статистический анализ данных, метод оболоченного анализа данных (DEA). 
В качестве данных для анализа будем использовать данные статистической отчетности 40 технопарков России (которые рассматривались в рамках рейтинга Ассоциации кластеров и технопарков России) за 2019 год. Данные для расчетов и анализа предоставлены Ассоциацией кластеров и технопарков России. Список необходимых для анализа показателей сформирован авторами самостоятельно.

Гипотеза исследования: эффективность функционирования инновационной инфраструктуры целесообразно оценивать посредством непараметрических методов анализа.

Научная новизна исследования заключается в попытке авторов совершенствовать методы оценки эффективности функционирования инновационной инфраструктуры.

Существующие подходы в научной литературе по оценке эффективности функционирования инфраструктуры инновационной деятельности, в том числе, технопарков обозначены автором в статье [5].

Результаты исследования и их обсуждение

Для оценки инновационной деятельности на уровне региона, эффективности функционирования региональных инновационных систем зачастую используются показатели системы инновационного экономического потенциала региона, который включает в себя: природноресурсный потенциал (туристический), трудовой (потребительский), инвестиционный, институциональный, производственный и финансовый потенциалы. При этом отдельными авторами «инновационный потенциал региона» определяется как «система ресурсного обеспечения функционирования любой социальноэкономической системы на мировом уровне или выше него...» [6].

Представляется, что институциональный элемент инновационного потенциала представляет собой совокупность инновационных инфраструктур, в том числе локальных инновационных систем, организационных структур, в рамках которых формируются, развиваются и потребляются инновационные продукты.

При этом подобного рода структуры и любые предприятия характеризуются определенной степенью инновационной активности, которая является характеристикой инновационной деятельности, определяемой, в том числе, степенью использования инновационного потенциала предприятия [7].

Под определением «технопарк» понимаются организации, созданные для внедрения научнотехнических и инновационных разработок в промышленность и другие виды экономической деятельности и предоставления компаниям оснащенной производственной, экспериментальной, информационной, инфраструктурной базы.

Присвоение статуса данного вида инновационной инфраструктуры носит заявительный характер. Подтверждение соответствия технопарка, а также управляющей компании технопарка требованиям, установленным Правительством Российской Федерации к технопарку и управляющим компаниям осуществляется уполномоченным органом в порядке, установленном Правительством Российской Федерации.

Для получения статуса технопарка предъявляется рад экономических и имущественных требований к собственникам, резидентам, управляющей компании, устанавливаемых уполномоченным органом исполнительной власти субъекта РФ.

Например, к таким требованиям в СанктПетербурге относятся: размер фонда оплаты труда за последний календарный год, суммарный объем инвестиций за последние 5 лет, объем выручки за последний год, общая площадь объектов капитального строительства, количество профильных и непрофильных объектов, недвижимое имущество, предназначенное для сдачи в аренду резидентам и др.

Методика оценки эффективности технопарков России законодательством не утверждена, оценка технологических парков производится в рамках проверки соответствия технопарка установленным требованиям при ежегодном подтверждении его статуса, а также при определении национального рейтинга технопарков России.

Национальный рейтинг технопарков России формируется на основании расчета 22 -х показателей, оценка производится по 5-ти блокам показателей, оценке подлежат показатели инновационной активности резидентов технопарка, экономической деятельности резидентов, эффективности деятельности управляющей компании технопарка, инвестиционной привлекательности, информационной открытости технопарка и вклада в устойчивое развитие [8].

Положительными чертами проводимой оценки являются использование различных от- 
носительных показателей, а также оценка различных направлений деятельности технопарка и его управляющей компании.

Среди недостатков оценки, проводимой в рамках формирования национального рейтинга технопарков, стоит отметить следующие:

- дублирование ряда показателей по различным направлениям оценки (например, наличие региональных льгот для резидентов);

- ряд абсолютных показателей не отражают эффективность работы технопарка (например, показатель «наличие инфраструктуры» не отражает эффективность работы технопарка, так как не анализирует эффективность её использования);

- не учитывается модель функционирования технопарка (университетская, инфраструктурная, инновационная, кооперативная);

- показатели не анализируются в динамике;

- показатели выбираются экспертами субъективно;

- рейтинг базируется в основном на статистических показателях, количественные данные рейтинга характеризуют результаты инновационной деятельности, но не описывают условия, по этой причине сложно определить, на основе чего образовались такие результаты деятельности;

- рейтинг не выделяет неэффективные технопарки, самая низкая в рейтинге группа технопарков имеет «достаточный уровень функционирования технопарка».

Кроме того, стоит отметить проблемы формирования статистических данных отчетности технопарков России. По этой причине выборка национального рейтинга технопарков России охватывает только 24\% технопарков России (технопарки, которые участвовали в оценке и предоставили необходимые данные).

Проанализируем показатели деятельности технопарков России за период с 2015 по 2019 год (табл. 1).

В целом, по всем показателям, статистику по которым удалось обнаружить, наблюдается ежегодный прирост (табл. 1). Количество технопарков с 2015 года выросло на 67\%. При этом площадные характеристики технопарков наоборот сократились - средняя площадь территории технопарка сократилась на 4\%, средняя площадь зданий и сооружений технопарков - на 17\%.

Количество технологичесих парков в России постепенно увеличивается, при этом количество регионов присутствия значительно не изменяется (рис. 1).

Количество объектов интеллектуальной собственности, зарегистрированных резидентами, с каждым годом увеличивается (рис. 2).

Проведенный анализ подходов к оценке эффективности функционирования объектов инновационной инфраструктуры и, в частности, технопарков позволяет выявить общность подходов, положительные черты и слабые места, присущие им.

Понятие эффективности так или иначе основывается на соотношении результатов и ресурсов. Производство считается эффективным при достижении максимального результата при заданном количестве ресурсов или при достижении заданного результата при минимизации использованных ресурсов. Согласно Купмансу Т. Ч. «производитель достигает технической эффективности, если дальнейшее увеличение одного из результатов вызывает сокращение, как минимум, одного из оставшихся результатов, либо рост затрат на хотя бы один из набора ресурсов, и, если при снижении количества одного ресурса увеличивается количество хотя бы одного другого ресурса или же снижается как минимум один из результатов» [9].

Для нашего исследования актуально определять, так называемую, техническую эффективность функционирования технопарков как экономической системы. Техническая эффективность в данном случае характеризует, насколько эффективно организация (в нашем случае технопарк) использует имеющиеся ресурсы. Техническая эффективность экономической системы направлена или на минимизацию затрат ресурсов, или на максимизацию результатов.

На первом этапе исследования для оценки технической эффективности технопарков в целом необходимо проследить связь между ресурсами технопарков и результатами их работы. Это необходимо для определения технологических парков России, в целом функционирующих эффективно, и сравнения полученных результатов оценки с результатами оценки Ассоциации кластеров и технопарков России. Кроме того, результаты первого этапа исследования позволят определить технически эффективные технопарки, которые не являются лидерами рейтинга Ассоциации кластеров и технопарков России.

Для расчета технической эффективности авторами был выбран метод оболоченного ана- 
Таблица 1. Показатели функционирования технопарков России в 2015-2019 гг

\begin{tabular}{|c|c|c|c|c|c|c|}
\hline $\begin{array}{c}\text { Показатели функционирования } \\
\text { технопарков России }\end{array}$ & 2019 & 2018 & 2017 & 2016 & 2015 & $\begin{array}{c}\text { Темп } \\
\text { прироста } \\
\text { базисный, } \\
\%\end{array}$ \\
\hline Количество, шт. & 179 & 169 & 157 & 125 & 107 & $67 \%$ \\
\hline $\begin{array}{l}\text { Количество регионов России (присут- } \\
\text { ствие) }\end{array}$ & 55 & 54 & 53 & 44 & 40 & $38 \%$ \\
\hline Количество резидентов, ед. & 5342 & 5087 & 4833 & 4317 & 4100 & $30 \%$ \\
\hline $\begin{array}{l}\text { Общее количество работников у рези- } \\
\text { дентов, чел. }\end{array}$ & 109760 & 91561 & 81607 & 73546 & 71200 & $54 \%$ \\
\hline Общая площадь территории, га & 1702,2 & 1592,6 & 1489,2 & 1058 & 920 & $85 \%$ \\
\hline $\begin{array}{l}\text { Общая площадь введенных в эксплуа- } \\
\text { тацию помещений технопарков, млн. } \\
\text { кв.м. }\end{array}$ & 4,8 & 4,5 & 4,2 & 3 & 2,7 & $78 \%$ \\
\hline Средняя площадь территории, га & 10,6 & 10,5 & 10,4 & 11,5 & 11 & $-4 \%$ \\
\hline $\begin{array}{l}\text { Совокупный объем налоговых отчис- } \\
\text { лений резидентов, млрд. руб. }\end{array}$ & 77,3 & 65,2 & 60,4 & 56,4 & 43,4 & $78 \%$ \\
\hline $\begin{array}{l}\text { Совокупный объём инвестиций рези- } \\
\text { дентов, млрд. руб. }\end{array}$ & 21,97 & 18,3 & 17,8 & 15,2 & 15,6 & $41 \%$ \\
\hline $\begin{array}{l}\text { Удельный объем инвестиций резиден- } \\
\text { тов технопарков, млн. руб./га }\end{array}$ & 21,9 & 11,5 & 12 & 14,4 & 16,9 & $30 \%$ \\
\hline $\begin{array}{l}\text { Привлечено инвестиций резидентов } \\
\text { на } 1 \text { рубль бюджетных инвестиций в } \\
\text { инфраструктуру, руб. }\end{array}$ & 9,3 & 9,3 & 5,8 & 10,2 & 3,5 & $166 \%$ \\
\hline $\begin{array}{l}\text { Совокупная выручка резидентов, } \\
\text { млрд. руб. }\end{array}$ & 294,7 & 270,3 & 240,9 & 203,5 & 188,6 & $56 \%$ \\
\hline $\begin{array}{l}\text { Средняя выручка на одного резидента, } \\
\text { млн. руб. }\end{array}$ & 55,2 & 53,1 & 49,8 & 48 & 46 & $20 \%$ \\
\hline $\begin{array}{l}\text { Совокупный объем выпуска импорто- } \\
\text { замещающей продукции, млрд. руб. }\end{array}$ & 48,5 & 35,9 & 32 & 27 & 26,4 & $84 \%$ \\
\hline $\begin{array}{l}\text { Количество объектов интеллектуаль- } \\
\text { ной собственности, зарегистрирован- } \\
\text { ных резидентами, ед. }\end{array}$ & 1523 & 1172 & 1065 & 900 & 860 & $77 \%$ \\
\hline $\begin{array}{l}\text { Средний объем затрат } 1 \text { резидента на } \\
\text { НИОКР, млн. руб. в год }\end{array}$ & 3,04 & 2,5 & 2,7 & 2,2 & 2,1 & $45 \%$ \\
\hline $\begin{array}{l}\text { Объем затрат одного резидента на } \\
\text { НИОКР в расчете на одного сотрудни- } \\
\text { ка, тыс. руб. в год }\end{array}$ & 184,6 & 150 & 146,5 & 147,1 & 145,4 & $27 \%$ \\
\hline Уровень занятости площадей,\% & 72,5 & 72,1 & 70,9 & 70,4 & 67 & $8 \%$ \\
\hline $\begin{array}{l}\text { Объем налоговых отчислений рези- } \\
\text { дентов на } 1 \text { рубль совокупных бюд- } \\
\text { жетных инвестиций в инфраструктуру, } \\
\text { руб. }\end{array}$ & 1,7 & 1,5 & 1,4 & 1,4 & 1,3 & $31 \%$ \\
\hline $\begin{array}{l}\text { Средний объем выручки управляющей } \\
\text { компании, млн. руб. }\end{array}$ & 266,5 & 195,2 & 133,2 & 136,8 & 114 & $134 \%$ \\
\hline $\begin{array}{l}\text { Средняя площадь зданий и сооруже- } \\
\text { ний технопарков, тыс. кв.м. }\end{array}$ & 27,1 & 27,1 & 26,9 & 23,4 & 32,8 & $-17 \%$ \\
\hline $\begin{array}{l}\text { Средняя плотность застройки терри- } \\
\text { тории технопарков, кв.м./га }\end{array}$ & 3756 & 2835,5 & 2835,5 & 2835 & 2934 & $28 \%$ \\
\hline $\begin{array}{l}\text { Инвестиции в инфраструктуру тех- } \\
\text { нопарков, млрд. руб. (бюджетные и } \\
\text { внебюджетные средства вместе) }\end{array}$ & 110,6 & 98,2 & 92,9 & 79 & 44,1 & $151 \%$ \\
\hline $\begin{array}{l}\text { Удельный объем инвестиций в инфра- } \\
\text { структуру технопарков, млн. руб./га }\end{array}$ & 61,6 & 61,6 & 62,4 & 74,7 & 47,9 & $29 \%$ \\
\hline
\end{tabular}

Составлено авторами на основании данных, опубликованных Ассоциацией кластеров и технопарков России в ежегодных обзорах «Технопарки России» URL: https://akitrf.ru/technoparks/analiticheskie-materialy/ (дата обращения: 28.12.2020). 


\section{Динамика развития технопарков России}

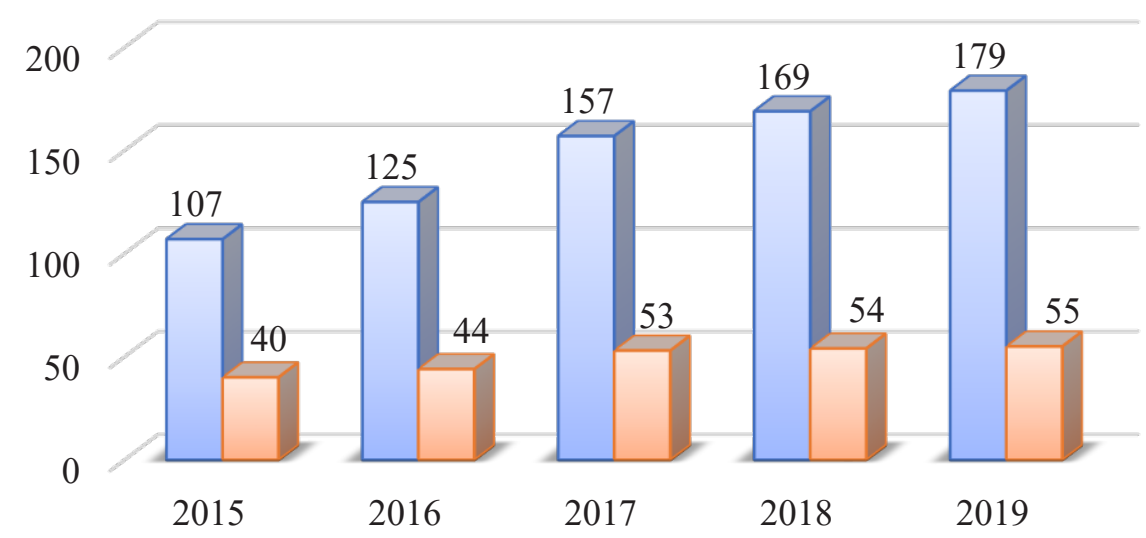

$\square$ Количество, шт. $\quad \square$ Количество регионов России (присутствие)

Рисунок 1. Динамика развития технопарков в России

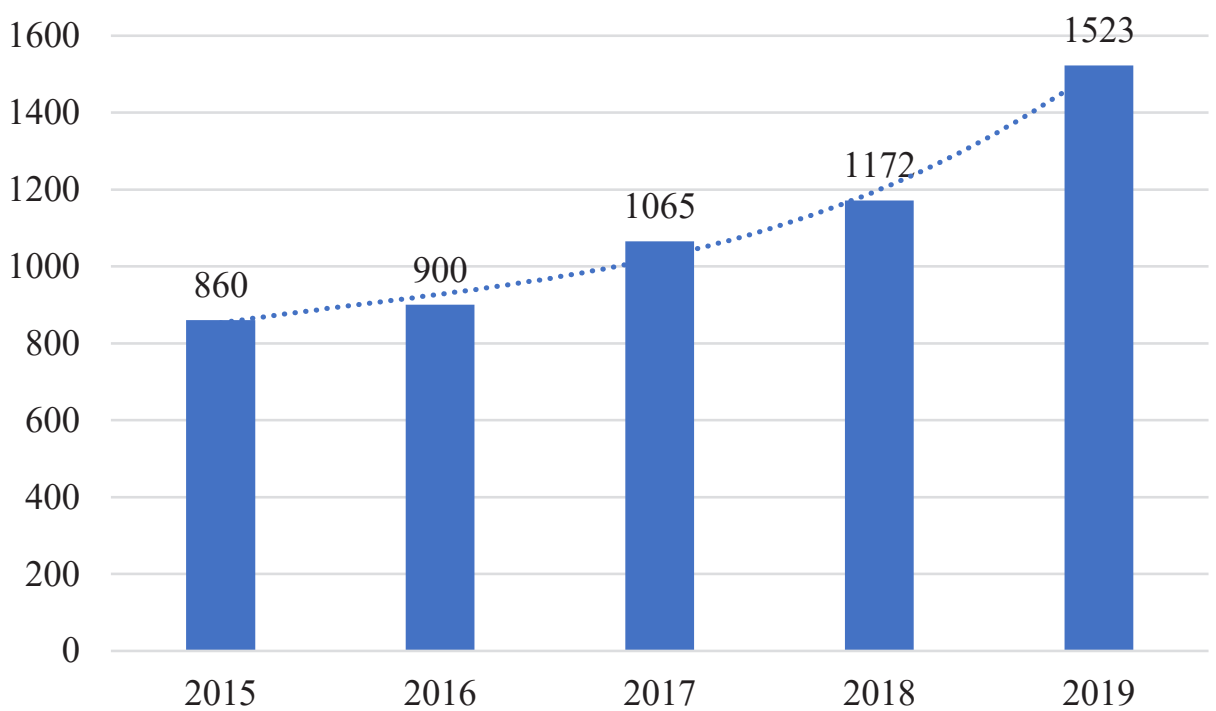

Рисунок 2. Количество объектов интеллектуальной собственности, зарегистрированных резидентами, ед.

лиза данных (Data Envelopment Analysis, DEA). Данный метод относится к непараметрическим подходам к оценке технической эффективности экономических систем.

В научных исследованиях данный метод зачастую используется для оценки эффективности национальных, региональных инновационных систем $[10,11]$, инновационной деятельности в промышленности и др. [12].

В подход DEA по сути заложена идеология бенчмаркинга, так как эффективные экономические единицы рассматриваются для других единиц как бенчмарки (образцы) [13].

Для достижения целей первого этапа исследования будем использовать модель CCR с постоянной отдачей от масштаба, ориентированную на результат (цель - максимизация показателей, входящих в группу «результаты»).

В качестве данных для анализа будем использовать данные статистической отчетности 40 технопарков России (которые рассматривались в рамках рейтинга Ассоциации кластеров и технопарков России) за 2019 год."

Авторами настоящего исследования принято

* Данные для расчетов и анализа предоставлены Ассоциацией кластеров и технопарков России. Список необходимых для анализа показателей сформирован авторами самостоятельно. 
решение об отсутствии временного лага между формированием ресурсов и результатов функционирования оцениваемых технопарков с учетом специфики выбранных показателей, поэтому ресурсы и результаты представлены одним временным периодом (по данным последней на дату исследования отчетности - 2019 г).

Экономической единицей, чья эффективность оценивается (decision-making unit, DMU), является технопарк России. Модель DEA позволяет автоматически рассчитать весовые значения каждого показателя для каждой экономической единицы.

Данные о выбранных для оценки ресурсах и результатах представлены в табл. 2 .

Для осуществления расчетов использовался пакет анализа Open Source DEA.*

Результаты расчетов для модели, ориентированной на результаты, представлены в табл. 3., рис. 3.

Таким образом, технически эффективные и неэффективные технопарки представлены в табл. 4.

В табл. 5 сопоставлены технически эффективные технопарки, определенные методом DEA и технопарки, отнесенные к наивысшему уровню эффективности функционирования технопарка (группа $(\mathrm{A}+)$ в соответствии с результатами VI Национального рейтинга технопарков России). Полужирным шрифтом выделены те технопарки, результаты определения эффективности по которым совпали. Технопарки под номерами $2,4,8,12$, указанные во втором столбце таблицы 5, по методу DEA получились технически неэффективными.

K преимуществам метода DEA относится возможность определить целевые значения ресурсов и результатов по каждому технопарку, позволяющие достичь технической эффективности.

\section{Заключение}

В статье рассмотрены существующие подходы к оценке эффективности технопарков, выделены их особенности, положительные стороны и недостатки. Выявлено, что методика оценки эффективности технопарков России законодательством не утверждена, оценка технологических парков производится в рамках проверки соответствия технопарка установленным требованиям при ежегодном подтверждении его статуса, а также при определении национального рейтинга технопарков России. Оценка в рамках указанного рейтинга основывается на определении ряда абсолютных и относительных показателей, отвечающих за различные направления работы технопарка.

Авторами данной статьи предложен иной подход к оценке эффективности производственно-технологической инфраструктуры инновационной деятельности посредством определения технической эффективности объекта исследования (максимизация результатов деятельности или минимизация ресурсов). Анализ произведен на примере технологических парков России.

Произведен расчет технической эффективности 40 технопарков России, полученные результаты эффективности сравнены с результатами национального рейтинга технопарков России 2019 года, формируемого Ассоциацией кластеров и технопарков России. Выявлены существенные различия в результатах рассматриваемых оценок.

Дальнейшие исследования будут направлены на совершенствование модели оценки эффективности производственно-технологической инфраструктуры инновационной деятельности посредством метода DEA, в том числе моделирование моделей оценки по стадиям инновационного процесса.

*https://opensourcedea.org/.

Таблица 2. Ресурсы и результаты, выбранные авторами для первого этапа исследования

\begin{tabular}{|c|c|}
\hline Ресурсы & Результаты \\
\hline $\begin{array}{l}\text { 1. Общее количество работников у резидентов, чел. } \\
\text { 2. Площадь помещений, тыс.кв.м. } \\
\text { 3. Совокупный объём инвестиций резидентов, млн. } \\
\text { руб. } \\
\text { 4. Объем затрат резидентов на НИОКР, млн. руб. } \\
\text { 5. Инвестиции в инфраструктуру технопарков, млн. } \\
\text { руб. (бюджетные средства). } \\
\text { 6. Инвестиции в инфраструктуру технопарков, млн. } \\
\text { руб. (внебюджетные средства). }\end{array}$ & $\begin{array}{l}\text { 1. Совокупный объем налоговых и таможенных } \\
\text { отчислений резидентов, млн. руб. } \\
\text { 2. Совокупная выручка резидентов, млн. руб. } \\
\text { 3. Количество объектов интеллектуальной соб- } \\
\text { ственности, зарегистрированных резидентами, ед. } \\
\text { (количество созданных результатов инновацион- } \\
\text { ной деятельности), ед. } \\
\text { 4. Объем экспорта продукции резидентов техно- } \\
\text { парка, млн. руб. }\end{array}$ \\
\hline
\end{tabular}


Таблица 3. Результаты расчетов технической эффективности технопарков

\begin{tabular}{|c|c|c|c|}
\hline $\begin{array}{l}\text { № } \\
\Pi / \Pi\end{array}$ & Технопарк & $\begin{array}{l}\text { Коэффициенты } \\
\text { эффективности }\end{array}$ & $\begin{array}{c}\text { Техническая } \\
\text { эффективность }\end{array}$ \\
\hline 1 & Промышленный технопарк «Электрополис» & 0.779440782 & \\
\hline 2 & Инновационно-производственный технопарк «Идея» & 1 & да \\
\hline 3 & Промышленный технопарк «ИКСЭл» & 1 & да \\
\hline 4 & Нанотехнологический центр «Техноспарк» & 1 & да \\
\hline 5 & Технопарк «Пермь» & 1 & да \\
\hline 6 & Технопарк «Полюс» & 0.860591578 & \\
\hline 7 & Центр нанотехнологий и наноматериалов Республики Мордовия & 0.711364049 & \\
\hline 8 & Технопарк «Маяк» & 0.145869039 & \\
\hline 9 & Технополис «Москва» & 0.735587721 & \\
\hline 10 & Технопарк «Строгино» & 1 & да \\
\hline 11 & Технопарк «Калибр» & 1 & да \\
\hline 12 & Технопарк в сфере высоких технологий Morion Digital & 1 & да \\
\hline 13 & Технопарк «СИГМА. Новосибирск» & 1 & да \\
\hline 14 & Технопарк Элма & 1 & да \\
\hline 15 & Технопарк «Якутия» & 1 & да \\
\hline 16 & Технопарк в сфере высоких технологий «ИТ-парк» & 0.703835384 & \\
\hline 17 & Научно-технологический парк Новосибирского Академгородка & 0.417596222 & \\
\hline 18 & Технопарк в сфере высоких технологий «Анкудиновка» & 1 & да \\
\hline 19 & Технопарк «Санкт-Петербург» & 1 & да \\
\hline 20 & Технопарк «Мосгормаш» & 1 & да \\
\hline 21 & Технопарк «Исток» & 1 & да \\
\hline 22 & Технопарк «Яблочков» & 1 & да \\
\hline 23 & Кузбасский технопарк & 1 & да \\
\hline 24 & Западно-Сибирский инновационный центр & 0.477072735 & \\
\hline 25 & Технопарк «Саров» & 0.705906441 & \\
\hline 26 & Технопарк в сфере высоких технологий «Рамеев» & 0.283609064 & \\
\hline 27 & Технопарк «Космос-нефть-газ» & 0.600906712 & \\
\hline 28 & Технопарк высоких технологий Свердловской области & 1 & да \\
\hline 29 & Технопарк Липецк & 0.479021357 & \\
\hline 30 & Технопарк «Ленполиграфмаш» & 0.894718605 & \\
\hline 31 & Инновационно-производственный технопарк «Идея-Юго-Восток» & 1 & да \\
\hline 32 & Ульяновский наноцентр (ULNANOTECH) & 1 & да \\
\hline 33 & Технопарк в сфере высоких технологий в Республике Мордовия & 0.704296103 & \\
\hline 34 & Технопарк в сфере высоких технологий «Жигулевская долина» & 0.569383015 & \\
\hline 35 & Технопарк «Подолье» & 1 & да \\
\hline 36 & Технопарк «Слава» & 1 & да \\
\hline 37 & Технопарк «Контакт» & 1 & да \\
\hline 38 & Технопарк «Можайский Первый» & 0.501574894 & \\
\hline 39 & Технопарк «Полимед» & 1 & да \\
\hline 40 & Технопарк высоких технологий, ХМАО-Югра & 0.448081815 & \\
\hline
\end{tabular}




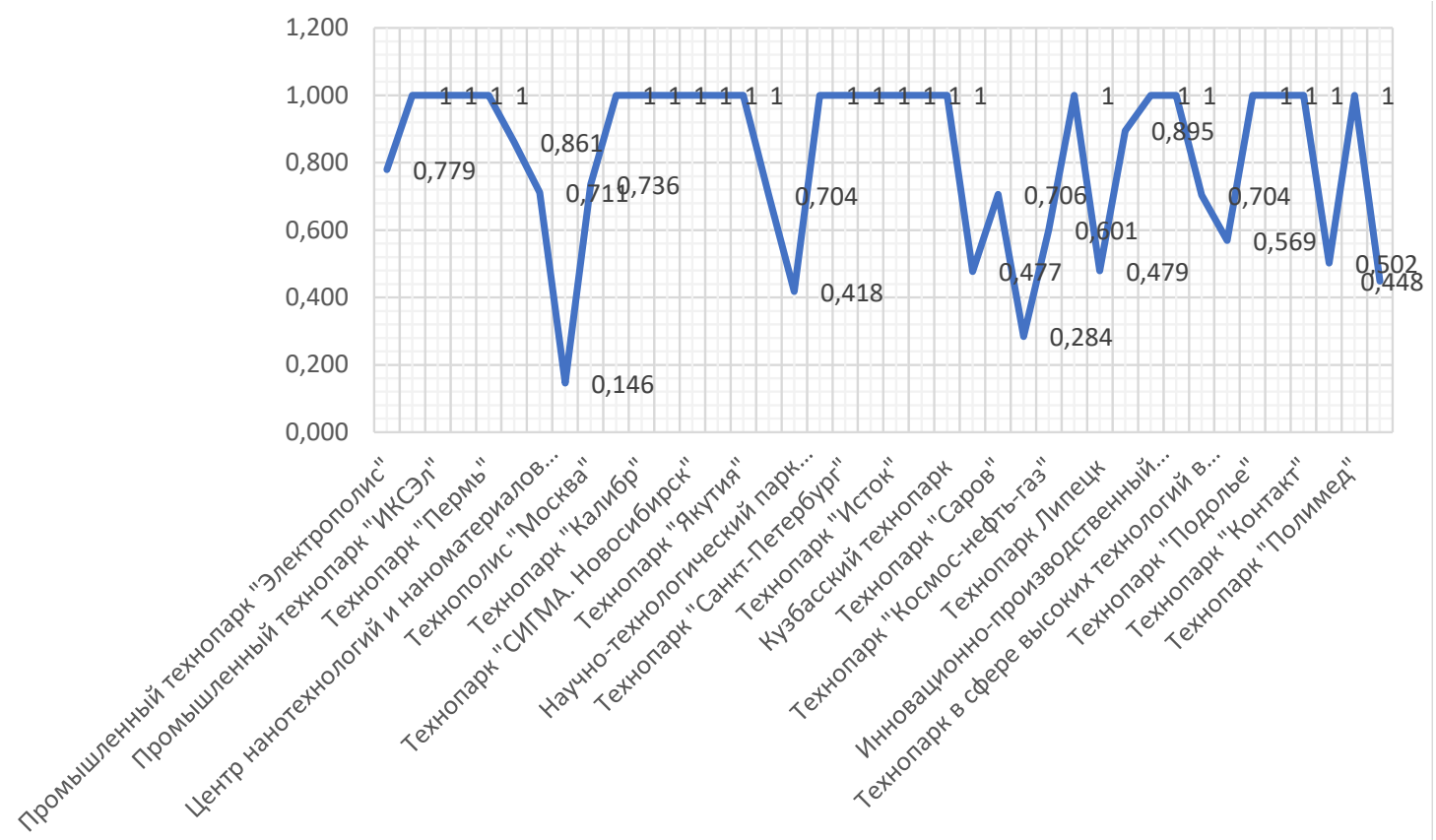

Рисунок 3. Техническая эффективность технологических парков России

Таблица 4. Технически эффективные и неэффективные технопарки

\begin{tabular}{|c|c|c|c|}
\hline $\begin{array}{c}\text { № } \\
\text { П/П }\end{array}$ & Эффективные технопарки & $\begin{array}{l}\text { № } \\
\text { П/П }\end{array}$ & Неэффективные технопарки \\
\hline 1 & $\begin{array}{l}\text { Инновационно-производственный технопарк } \\
\text { «Идея» }\end{array}$ & 1 & Промышленный технопарк «Электрополис» \\
\hline 2 & Промышленный технопарк «ИКСЭл» & 2 & Технопарк «Полюс» \\
\hline 3 & Нанотехнологический центр «Техноспарк» & 3 & $\begin{array}{l}\text { Центр нанотехнологий и наноматериалов Респу- } \\
\text { блики Мордовия }\end{array}$ \\
\hline 4 & Технопарк «Пермь» & 4 & Технопарк «Маяк» \\
\hline 5 & Технопарк «Строгино» & 5 & Технополис «Москва» \\
\hline 6 & Технопарк «Калибр» & 6 & Технопарк в сфере высоких технологий «ИТ-парк» \\
\hline 7 & $\begin{array}{l}\text { Teхнопарк в сфере высоких технологий Morion } \\
\text { Digital }\end{array}$ & 7 & $\begin{array}{l}\text { Научно-технологический парк Новосибирского } \\
\text { Академгородка }\end{array}$ \\
\hline 8 & Технопарк «СИГМА. Новосибирск» & 8 & Западно-Сибирский инновационный центр \\
\hline 9 & Технопарк Элма & 9 & Технопарк «Саров» \\
\hline 10 & Технопарк «Якутия» & 10 & Технопарк в сфере высоких технологий «Рамеев» \\
\hline 11 & $\begin{array}{l}\text { Технопарк в сфере высоких технологий «Анку- } \\
\text { диновка» }\end{array}$ & 11 & Технопарк «Космос-нефть-газ» \\
\hline 12 & Технопарк «Санкт-Петербург» & 12 & Технопарк Липецк \\
\hline 13 & Технопарк «Мосгормаш» & 13 & Технопарк «Ленполиграфмаш» \\
\hline 14 & Технопарк «Исток» & 14 & $\begin{array}{l}\text { Технопарк в сфере высоких технологий в Респу- } \\
\text { блике Мордовия }\end{array}$ \\
\hline 15 & Технопарк «Яблочков» & 15 & $\begin{array}{l}\text { Технопарк в сфере высоких технологий «Жигулев- } \\
\text { ская долина» }\end{array}$ \\
\hline 16 & Кузбасский технопарк & 16 & Технопарк «Можайский Первый» \\
\hline 17 & $\begin{array}{l}\text { Технопарк высоких технологий Свердловской } \\
\text { области }\end{array}$ & 17 & Технопарк высоких технологий, ХМАО-Югра \\
\hline 18 & $\begin{array}{l}\text { Инновационно-производственный технопарк } \\
\text { «Идея-Юго-Восток» }\end{array}$ & & \\
\hline 19 & Ульяновский наноцентр (ULNANOTECH) & & \\
\hline 20 & Технопарк «Подолье» & & \\
\hline 21 & Технопарк «Слава» & & \\
\hline 22 & Технопарк «Контакт» & & \\
\hline 23 & Технопарк «Полимед» & & \\
\hline
\end{tabular}


Таблица 5. Эффективные технопарки России

\begin{tabular}{|c|c|}
\hline $\begin{array}{l}\text { Эффективные технопарки России по методу DEA } \\
\text { (техническая эффективность = 1) }\end{array}$ & $\begin{array}{l}\text { Наивысший уровень эффективности функциони- } \\
\text { рования технопарка (I группа (А+) в соответствии } \\
\text { с результатами VI Национального рейтинга тех- } \\
\text { нопарков России [7] }\end{array}$ \\
\hline $\begin{array}{l}\text { 1. Инновационно-производственный технопарк } \\
\text { «Идея» } \\
\text { 2. Промышленный технопарк «ИКСЭл» } \\
\text { 3. Нанотехнологический центр «Техноспарк» } \\
\text { 4. Технопарк «Пермь» } \\
\text { 5. Технопарк «Строгино» } \\
\text { 6. Технопарк «Калибр» } \\
\text { 7. Технопарк в сфере высоких технологий Morion } \\
\text { Digital } \\
\text { 8. Технопарк «СИГМА. Новосибирск» } \\
\text { 9. Технопарк Элма } \\
\text { 10. Технопарк «Якутия» } \\
\text { 11. Технопарк в сфере высоких технологий «Ан- } \\
\text { кудиновка» } \\
\text { 12. Технопарк «Санкт-Петербург» } \\
\text { 13. Технопарк «Мосгормаш» } \\
\text { 14. Технопарк «Исток» } \\
\text { 15. Технопарк «Яблочков» } \\
\text { 16. Кузбасский технопарк } \\
\text { 17. Технопарк высоких технологий Свердловской } \\
\text { области } \\
\text { 18. Инновационно-производственный технопарк } \\
\text { «Идея-Юго-Восток» } \\
\text { 19. Ульяновский наноцентр (ULNANOTЕСН) } \\
\text { 20. Технопарк «Подолье» } \\
\text { 21. Технопарк «Слава» } \\
\text { 22. Технопарк «Контакт» } \\
\text { 23. Технопарк «Полимед» }\end{array}$ & $\begin{array}{l}\text { 1. Нанотехнологический центр «Техноспарк» } \\
\text { 2. Технопарк в сфере высоких технологий в Республи- } \\
\text { ке Мордовия } \\
\text { 3. Технопарк высоких технологий Свердловской } \\
\text { области } \\
\text { 4. Технопарк в сфере высоких технологий «Жигулев- } \\
\text { ская долина» } \\
\text { 5. Tехнопарк в сфере высоких технологий Morion } \\
\text { Digital } \\
\text { 6. Технопарк «Калибр» } \\
\text { 7. Технопарк в сфере высоких технологий «Анку- } \\
\text { диновка» } \\
\text { 8. Технопарк в сфере высоких технологий «Рамеев» } \\
\text { 9. Технопарк «Слава» } \\
\text { 10.Инновационно-производственный технопарк } \\
\text { «Идея» } \\
\text { 11. Ульяновский наноцентр (ULNANOTЕСН) } \\
\text { 12. Научно-технологический парк Новосибирского } \\
\text { Академгородка «Академпарк» }\end{array}$ \\
\hline
\end{tabular}

\section{Библиографический список}

1. Харин А.А.Инновационная инфраструктура как основной элемент национальной инновационной системы // Науковедческие исследования. № 2015. 2015, с. 12-18.

2. Ханчук Н.Н., Семке Ю. С. Роль инновационной инфраструктуры в региональной инновационной системе // Вестник Забайкальского гос. ун-та. 2016. T. 22. № 6, с. 124-133. DOI: 10.21209/2227-9245-2016-22-6-124133.

3. Чистякова О.В.Производственно-технологическая инфраструктура инновационной предпринимательской деятельности в ресурсно-ориентированных регионах // Исследования Байкальского государственного университета. 2018. Т. 28. № 4. C. 682-693. DOI: 10.17150/2500-2759.2018.28(4).682-693.

4. Земцов С. П. Инновационная зона как территориальная модель модернизации экономики России // Региональные исследования. 2009. № 4-5(25), с. 14-23.

5. Кох Ю.П. К вопросам проектирования и оценки эффективности локальных инновационных систем на мезоуровне // Креативная экономика.-2020.- Том 14. - № 10.-doi: 10.18334/ce.14.10.111010.

6. Жиц Г. И. Инновационный потенциал и экономический рост.- Саратов: Сарат. гос. техн. ун-т, 2000. - 164 с.

7. Родионов Д.Г., Кошман А.В., Моттаева А.Б. Инструментальные методы оценки влияния инновационной активности хозяйствующего субъекта на стоимость бизнеса // Вестник алтайской академии экономики и права. 2019. № 12-3, с. 122-131.

8. Бухарова М.М., Данилов Л. В., Кашинова Е.А. и др. // Технопарки России: ежегодный обзор. Ассоциация развития кластеров и технопарков России. Том 6.- М.: АКИТ РФ, 2020-110 с.: ил.- 1500 экз. ISBN 978-59500897-9-4.

9. Koopmans, T.C. (1951). Analysis of production as an efficient combination of activities. In: T. C. Koopmans (ed.). Activity Analysis of Production and Allocation. New York: John Wiley \& Sons. P. 33-37.

10. Рудская И. А. Моделирование оценки эффективности региональной инновационной системы России // Инновации. № 10 (228). 2017, с. 40-45. 
11. Zemtsov, S., \& Kotsemir, M. (2019). An assessment of regional innovation system efficiency in Russia: the application of the DEA approach. Scientometrics, 120(2), 375-404.

12. Колоскова О.И. Инструментально-методические аспекты оценки эффективности инновационной деятельности в промышленности // Современная экономика: проблемы и решения. № 12 (120). 2019. С. $154-167$.

13. Родионов Д.Г., Цыпкин Ю.В., Синельникова С. С. Эффективность функционирования технопарков и бизнесинкубаторов // Научно-технические ведомости Санкт-Петербургского политехнического университета. Экономические науки. № 4(151). 2012, с. 150-159. 